\title{
Influence of a Protein Concentrate Used as a Fat Substitute on the Quality of Cheese Bread
}

\author{
Silvia Silveira Clareto, David Lee Nelson and Accácia Júlia Guimarães Pereira* \\ Departamento de Alimentos; Faculdade de Farmácia; Universidade Federal de Minas Gerais; 31270-901; \\ acaciaju@netuno.lcc.ufmg.br; Belo Horizonte - MG - Brasil
}

\begin{abstract}
The effects of the use of a protein concentrate as a fat substitute on the quality of cheese bread were investigated. Based on a 10\% basic fat formulation, the substitution of 10, 25, 50, 75 and 100\% of the oil in the formula was tested. Physical characteristics were measured, and sensorial parameters were determined. The products with lower levels of fat substitute had higher levels of acceptability. With the increase in the degree of substitution, the cheese bread products were harder, had a thicker crust and presented a less pleasant appearance, less pronounced cheese flavor and a lower degree of acceptance. The use of a fat substitute resulted in a product with a significantly lower fat content and a caloric reduction greater than $25 \%$.
\end{abstract}

Key words: Cheese bread, fat substitute, caloric reduction, lipid reduction

\section{INTRODUCTION}

Cheese bread is a typical product of the state of Minas Gerais, Brazil, being widely commercialized and consumed throughout the country. No standardized technology exists for its production, varying with the producer. Despite this variability, the method of production adopted by the large majority of the producers utilizes cassava starch, cheese, vegetable oil, eggs, whole milk and salt as raw materials. A basic procedure of gelatinizing (scalding) the cassava starch with hot water, vegetable oil or milk, kneading with eggs, adding the cheese and baking is used (Pereira, 1998). However, this product presents a very high caloric value compared to other foods. Each baked unit of about $24 \mathrm{~g}$ contains an average of $85 \mathrm{kcal}$. The most important factor in reducing the caloric value is the reduction in the fat content, the most concentrated energy source in the diet, furnishing
$9 \mathrm{kcal} / \mathrm{g}$ compared with $4 \mathrm{kcal} / \mathrm{g}$ for proteins and carbohydrates (Akoh, 1998).

Since an excess of fat in the diet is associated with obesity, some types of cancer, a high blood cholesterol level and an increase in the risk of cardiovascular disease, attempts have been made to produce foods with the organoleptic and functional properties of fats without the high caloric content (Akoh, 1998; Cândido and Campos, 1995). High fat levels can be efficiently reduced through the use of ingredients that simulate the functions of fats and/or accentuate those properties (Barnes and Antenucci, 1993). Such ingredients are called fat substitutes and exercise some or all of the functions of fats, with or without nutritional value (Akoh, 1998; Cândido and Campos, 1995).

The Pfizer-Food Science Group, associated with the Ault Foods Dairy, developed a product from milk whey proteins, naming it Dairy-lo. This

* Author for correspondence 
product, patented by Cultor Food Science, is used with the aim of improving the creamy mouth feel, control the viscosity and confer stability at low temperatures (crystallization inhibitor) in low fat products. Its texture is soft and not sandy. Its caloric content is $4 \mathrm{kcal} / \mathrm{g}$, being composed of $35 \%$ protein, $3.5 \%$ fat, $52 \%$ carbohydrates and less than 9\% fiber. The principal protein in Dairy-lo is $\beta$ lactoglobulin, a globular protein in its native state (Lucca and Tepper, 1994; Mitchell, 1993).

Considering the economic and social importance of cheese bread for the state of Minas Gerais, the work described herein had the objective of supplying subsidies for the caloric reduction of this product through the use of a protein concentrate as a fat substitute.

\section{MATERIAL AND METHODS}

Cassava starch, cheese, eggs, whole milk, vegetable oil and iodated table salt used for the fabrication of the cheese bread were acquired locally in quantities sufficient for all of the experiments. The fat substitute was the Dairy-lo protein concentrate produced by Cultor Food Science. Cured Minas cheese and parmesan cheese were selected from the varieties commercially available. The cheeses were mixed in the proportion of $80 \%$ cured Minas cheese and 20\% Parmesan cheese, packed and frozen to avoid any deterioration.

\section{Production of cheese bread}

Preliminary experiments were performed to develop a formulation with a lower oil content than that of Jesus (1997), while maintaining the same level of acceptance as that of the original formula. The formulation of Jesus [100 g cassava starch, $25 \mathrm{~g}$ water, $25 \mathrm{~g}$ oil $(25 \%$ based on the quantity of cassava starch utilized), $25 \mathrm{~g}$ milk, $20 \mathrm{~g}$ eggs, $25 \mathrm{~g}$ cheese and $1.0 \mathrm{~g}$ salt] is very similar to that used by the majority of the cheese bread factories and was designated P2. The cheese bread obtained in this study was produced according to the process and formula described by Pereira et al. (1995) and Clareto (2000): $100 \mathrm{~g}$ cassava starch, $25 \mathrm{~g}$ water, $10 \mathrm{~g}$ oil ( $10 \%$ based on the quantity of cassava starch utilized), $25 \mathrm{~g}$ milk, $20 \mathrm{~g}$ eggs, $25 \mathrm{~g}$ cheese and $1.0 \mathrm{~g}$ salt. This formulation was designated P1 and was used as the basis for the substitution of the oil by the fat substitute. The substitution of $10,25,50,75$ and $100 \%$ of the oil was tested to determine the influence on the quality of the product. The fat substitute was used in the dry form and mixed with the cassava starch. After shaping, the dough was frozen during a period of three hours at an average temperature of $-18{ }^{\circ} \mathrm{C}$ and placed in polyethylene bags that were sealed and stored in a freezer. The samples were baked under standardized conditions of time (30 min) and temperature $\left(180{ }^{\circ} \mathrm{C}\right)$ in an electric oven equipped with a temperature controller (Fornax) and submitted to sensory evaluation, determination of physical properties and color analysis.

\section{Physical and chemical characterization of the cassava starch}

Determinations of the acidity and $\mathrm{pH}$ and density of the cassava starch were performed in triplicate. The acidity was determined by titration of a suspension containing $10 \mathrm{~g}$ of starch in $100 \mathrm{~mL}$ of distilled water with $0.1 \quad \mathrm{~N} \quad \mathrm{NaOH}$ using phenolphthalein as indicator as described in the Normas Analiticas of the Instituto Adolfo Lutz (IAL, 1985). The $\mathrm{pH}$ was measured using a potenciometer after preparing the sample as recommended (IAL, 1985). The density was determined by weighing a known volume of the sample.

\section{Sensorial analysis of cheese bread}

The sensory analyses were performed 15 minutes after baking by a panel of 12 untrained testers. The attributes were established by Jesus (1997). A descriptive test (Anzaldua-Morales, 1994) with a structured five-point scale was used. The scale varied from "very good" (5) to "very bad" (1) for appearance; "very strong" to "very weak" for cheese flavor; "very hard" to "very soft" for brittleness (crunchiness) of the crust; "very thick" to "very thin" for the thickness of the crust; "very sticky" to "very spongy" for the texture of the center; and "liked very much" to "disliked very much" for the degree of satisfaction.

\section{Physical analyses of cheese bread}

Measurements of density, crust thickness, linear growth and expansion coefficient were performed on six samples. 


\section{a) Density of the raw dough and of the cheese bread}

The densities of the raw dough and of the cheese bread were determined by measuring the volume of millet seeds displaced by the weighed sample (Griswold, 1972). The flask to be used for determining the respective volumes was filled to the brim with millet seeds and the volume of the seeds was measured with a graduated cylinder. The weighed sample (dough or bread) was placed in the flask and the flask was again filled with millet seeds. The volume of the seeds was again measured, and the volume of the sample was calculated from the difference in the volumes of the millet seeds with and without the sample.

\section{b) Crust thickness}

The cheese breads were cut in half horizontally, the thickness of the upper and lower crusts was measured at four different points with a caliper, and the average thickness was calculated.

\section{c) Linear growth}

The dough was placed in baking recipients having a diameter of $40 \mathrm{~mm}$. The heights of the baking recipients and the cheese bread in the baking recipients after baking were measured with a caliper. The linear growth $\left(C_{L}\right)$ was represented by the height that the dough grew beyond the borders of the form.

\section{d) Expansion coefficient}

The expansion coefficient $\left(\mathrm{C}_{\mathrm{e}}\right)$ was calculated from the following equation:

$$
C_{e}=\frac{V_{2}-V_{1}}{V_{1}} \times 100
$$

where $\mathrm{C}_{\mathrm{e}}=$ expansion coefficient in $\% ; \mathrm{V}_{2}=$ volume of the cheese bread; $V_{1}=$ volume of the raw dough

\section{e) Color characteristics}

The reference cheese bread sample and those prepared using the fat substitute were baked and the crust was separated from the center. These were ground in a blender and sifted after airdrying. The samples were analyzed in triplicate.

A ColorTec - PCM (Accuracy Microsensor Inc., Pittsford, New York) colorimeter was employed for determination of the color characteristics. The parameters $\mathrm{L}^{*}, \mathrm{a}^{*}$ and $\mathrm{b}^{*}$ were determined for the crust and the center of the cheese bread. $\mathrm{L}^{*}$ (luminosity or brilliance) varied from black (zero) to white $(100), a^{*}$ from green $\left(-a^{*}\right)$ to red $\left(+a^{*}\right)$ and $b^{*}$ from blue $\left(-b^{*}\right)$ to yellow $\left(+b^{*}\right)$. The formula $\Delta \mathrm{E}=\left(\Delta \mathrm{L}^{* 2}+\Delta \mathrm{a}^{* 2}+\Delta \mathrm{b}^{* 2}\right)^{1 / 2}$ was used to calculate the difference in color between the reference product and the samples containing the fat substitute, where $\Delta \mathrm{E}=$ difference in color; $\Delta \mathrm{L}$ $=$ difference in luminosity; $\Delta \mathrm{a}=$ difference in the red color; $\Delta \mathrm{b}=$ difference in the yellow color.

\section{Statistical analysis}

A random block experimental description was employed. The results were submitted to analysis of variance using the Duncan test at $5 \%$ of probability for comparison of the means (Montgomery, 1984; Shirose and Mori, 1994; Wonnacott and Wonnacott, 1985).

\section{Calculation of the caloric and lipid contents and the cost of the the cheese bread}

The caloric content of the product was calculated by multiplying the percentage of each ingredient by the caloric value encountered in the tables of chemical composition of foods elaborated by Franco (1992). The same procedure was used to calculate the lipid content of the cheese bread, multiplying the percentage of each ingredient by its respective lipid content. A calorie content of $400 \mathrm{kcal} / 100 \mathrm{~g}$ and a lipid content of $3.5 \mathrm{~g} / 100 \mathrm{~g}$ of product was used in the case of the fat substitute. The values for $100 \mathrm{~g}$ of product were calculated from the formula:

$100\left[\sum\right.$ (mass of the ingredient $\mathrm{x}$ caloric content or lipid content $) / \sum$ (mass of the ingredients)].

The cost per kilogram of product was calculated using the formula:

$1000\left[\sum\right.$ (mass of ingredient $x$ cost) $/ \sum$ (mass of the ingredients)].

The formula $100\left[\left(\mathrm{~V}_{1}-\mathrm{V}_{2}\right) / \mathrm{V}_{1}\right]$, where $\mathrm{V}_{1}$ is the caloric content (or lipid content) of the reference cheese bread and $\mathrm{V}_{2}$ is that of the test sample, was used to calculate the reduction in calories of the cheese bread. 


\section{RESULTS AND DISCUSSION}

\section{Characterization of the Cassava starch}

The mean physical-chemical properties determined (in triplicate) for the cassava starch were $\mathrm{pH}=3.66$, a titratable acidity of $4.68 \mathrm{~mL} 1.0$ $\mathrm{N} \mathrm{NaOH} / 100 \mathrm{~g}$ and a density of $0.66 \mathrm{~g} / \mathrm{mL}$.

\section{Sensorial Characteristics}

The mean results of the sensorial analyses of the cheese breads produced with the Dairy-lo protein concentrate are presented in Table 1. The scores for the appearance of the cheese breads produced with Dairy-lo decreased with the increase in the degree of substitution of the fat content. However, no significant differences among the samples were registered. All were considered as having a medium (3) to good (4) appearance.

The cheese flavor of the cheese breads was not affected by the use of Dairy-lo. All the samples had a flavor characterized as weak (2) to moderate (3). With respect to the crunchiness of the crust, there was a significant difference between the cheese bread produced with complete fat substitution and the others that had softer crusts. The crusts became thicker with the increase in the level of addition of Dairy-lo, but only the cheese bread with total substitution of the fat presented a crust of intermediate thickness; the remaining samples had thinner crusts.

The cheese bread preferred by the testers was that with $10 \%$ substitution. A small decrease in the degree of satisfaction with an increase in the concentration of fat substitute was observed (correlation coefficient $\mathrm{r}=-0.91$ ). There was a small decrease in the quality of the product with an increase in the fat substitute level for all of the attributes since the cheese bread with complete substitution of the fat received the lowest score.

Table 1 - Results of the sensorial analysis of the cheese breads produced with partial substitution of the fat by a protein concentrate

\begin{tabular}{lccccc}
\hline & \multicolumn{5}{c}{ Level of substitution (\%) } \\
\cline { 2 - 6 } \multicolumn{1}{c}{ Attributes } & $\mathbf{1 0}$ & $\mathbf{2 5}$ & $\mathbf{5 0}$ & $\mathbf{7 5}$ & $\mathbf{1 0 0}$ \\
\hline Appearance & $3.89^{\mathrm{a}}$ & $3.83^{\mathrm{a}}$ & $3.78^{\mathrm{a}}$ & $3.64^{\mathrm{a}}$ & $3.50^{\mathrm{a}}$ \\
Cheese taste & $2.56^{\mathrm{a}}$ & $2.36^{\mathrm{a}}$ & $2.53^{\mathrm{a}}$ & $2.39^{\mathrm{a}}$ & $2.53^{\mathrm{a}}$ \\
Crunchiness of the crust & $2.39^{\mathrm{b}}$ & $2.06^{\mathrm{c}}$ & $2.42^{\mathrm{b}}$ & $2.42^{\mathrm{b}}$ & $2.89^{\mathrm{a}}$ \\
Thickness of the crust & $2.33^{\mathrm{b}}$ & $2.36^{\mathrm{b}}$ & $2.47^{\mathrm{b}}$ & $2.50^{\mathrm{b}}$ & $2.97^{\mathrm{a}}$ \\
Texture of the center & $2.76^{\mathrm{a}}$ & $2.86^{\mathrm{a}}$ & $2.79^{\mathrm{a}}$ & $2.89^{\mathrm{a}}$ & $2.92^{\mathrm{a}}$ \\
Degree of satisfaction & $3.78^{\mathrm{a}}$ & $3.51^{\mathrm{a} . \mathrm{b}}$ & $3.61^{\mathrm{a}}$ & $3.44^{\mathrm{a} . \mathrm{b}}$ & $3.28^{\mathrm{b}}$ \\
\hline
\end{tabular}

"Means of the scores given by the sensorial panel (three repetitions) using descriptive tests and a structured scale of five points. Statistical analysis utilized the Duncan test at $5 \%$ probability; values in the same line followed by the same letter do not present significant differences.

\section{Physical properties}

The mean results of the measurements of the physical properties of cheese bread prepared with Dairy-lo are presented in Table 2. There was an increase in the density and thickness of the crust of the cheese bread with an increase in the level of substitution. The sample that presented the thinnest crust was that with $10 \%$ of fat substitute. The crust of cheese breads with 75 and $100 \%$ substitution were thicker, being statistically different from the remaining samples. The linear growth and the expansion coefficient of the cheese bread decreased with the increase in the level of fat substitute. The calculated correlation coefficients (-0.91 and -0.98 , respectively) confirmed this tendency. The linear growth in the samples with 10 and $25 \%$ of substitution was significantly greater, being different from the others.

\section{Color characteristics}

The color characteristics of the cheese breads produced with protein concentrate are presented in Table 3 . The crust and the center became more yellow with the increase in the degree of fat substitution. These data confirmed the information supplied by the factory that indicated the capacity of Dairy-lo to produce a good appearance and a yellow color in the products in which it is used. The higher the degree of substitution of the fat, the greater was the difference in the color of the reference cheese bread and the samples. 
Table 2 - Influence of the level of substitution by protein concentrate on the physical properties of cheese bread.

\begin{tabular}{|c|c|c|c|c|c|c|c|}
\hline \multirow{2}{*}{\multicolumn{2}{|c|}{ Physical Properties* }} & \multicolumn{6}{|c|}{ Degree of Substitution (\%) } \\
\hline & & $\mathbf{0}$ & $\mathbf{1 0}$ & 25 & $\mathbf{5 0}$ & 75 & 100 \\
\hline \multirow[t]{2}{*}{ Density $(\mathrm{g} / \mathrm{mL})$} & Raw dough & 1.37 & $1.12^{\mathrm{d}}$ & $1.14^{\mathrm{c.d}}$ & $1.18^{\mathrm{b} . \mathrm{c}}$ & $1.23^{\mathrm{a} . \mathrm{b}}$ & $1,25^{\mathrm{a}}$ \\
\hline & Cheese bread & 0.50 & $0.44^{\mathrm{d}}$ & $0.46^{\mathrm{c.d}}$ & $0.47^{\text {b.c }}$ & $0.49^{\text {a.b }}$ & $0,50^{\mathrm{a}}$ \\
\hline \multicolumn{2}{|c|}{ Thickness of the crust (mm) } & 2.66 & $1.27^{\mathrm{c}}$ & $1.30^{\mathrm{c}}$ & $1.38^{\mathrm{b}}$ & $1.43^{\mathrm{a}}$ & $1.45^{\mathrm{a}}$ \\
\hline \multicolumn{2}{|c|}{ Linear growth $(\mathrm{mm})$} & 18.09 & $20.27^{\mathrm{a}}$ & $20.56^{\mathrm{a}}$ & $19.37^{\mathrm{b}}$ & $19.33^{\mathrm{b}}$ & $18.09^{\mathrm{c}}$ \\
\hline \multicolumn{2}{|c|}{ Expansion coefficient (\%) } & 105.52 & $107.10^{\mathrm{a}}$ & $105.63^{\mathrm{a}}$ & $104.78^{\mathrm{a}}$ & $104.17^{\mathrm{a}}$ & $103.60^{\mathrm{a}}$ \\
\hline
\end{tabular}

* Mean of three repetitions of the measurements of six samples of cheese bread. Statistical analysis was performed by the Duncan test at $5 \%$ of probability. There was no significant difference between values on the same line followed by the same letter.

Table 3 - Evaluation of the color parameters of samples of cheese bread containing protein concentrate.

\begin{tabular}{lccccccc}
\hline & & \multicolumn{5}{c}{ Degree of Substitution (\%) } \\
\cline { 3 - 8 } & $\begin{array}{c}\text { Color } \\
\text { parameters }\end{array}$ & $\mathbf{0}$ & $\mathbf{1 0}$ & $\mathbf{2 5}$ & $\mathbf{5 0}$ & $\mathbf{7 5}$ & $\mathbf{1 0 0}$ \\
\hline Crust & $\mathrm{L}^{*}$ & 95.63 & $95.66^{\mathrm{b}}$ & $95.47^{\mathrm{b}}$ & $97.03^{\mathrm{a}}$ & $96.89^{\mathrm{a}}$ & $92.75^{\mathrm{c}}$ \\
& $\mathrm{a}^{*}$ & $1.67^{\mathrm{a}}$ & $1.52^{\mathrm{a}}$ & $0.96^{\mathrm{b}}$ & $0.87^{\mathrm{b}}$ & $0.54^{\mathrm{b}}$ & $1.36^{\mathrm{a}}$ \\
& $\mathrm{b}^{*}$ & 21.80 & $22.54^{\mathrm{b}}$ & $23.10^{\mathrm{a} . \mathrm{b}}$ & $23.38^{\mathrm{a} . \mathrm{b}}$ & $22.66^{\mathrm{a} . \mathrm{b}}$ & $23.64^{\mathrm{a}}$ \\
\hline Center & $\mathrm{L}^{*}$ & 89.98 & $90.31^{\mathrm{b}}$ & $90.38^{\mathrm{b}}$ & $90.48^{\mathrm{b}}$ & $91.23^{\mathrm{b}}$ & $97.66^{\mathrm{a}}$ \\
& $\mathrm{a}^{*}$ & 2.02 & $2.56^{\mathrm{a}}$ & $1.96^{\mathrm{a} . \mathrm{b}}$ & $2.45^{\mathrm{a}}$ & $1.51^{\mathrm{b}}$ & $0.62^{\mathrm{c}}$ \\
& $\mathrm{b}^{*}$ & 22.53 & $22.51^{\mathrm{a}}$ & $22.75^{\mathrm{a}}$ & $22.88^{\mathrm{a}}$ & $22.90^{\mathrm{a}}$ & $22.40^{\mathrm{a}}$ \\
\hline Crust & $\Delta \mathrm{E}$ & - & $3.08^{\mathrm{a}}$ & $1.68^{\mathrm{a}}$ & $4.82^{\mathrm{a}}$ & $2.39^{\mathrm{a}}$ & $17.73^{\mathrm{b}}$ \\
Center & $\Delta \mathrm{E}$ & - & $1.48^{\mathrm{a}}$ & $1.67^{\mathrm{a}}$ & $2.29^{\mathrm{a}}$ & $3.93^{\mathrm{a}}$ & $31.44^{\mathrm{b}}$ \\
\hline
\end{tabular}

*Means of three readings each of three cheese bread dough samples. Statistical analysis was performed by the Duncan test at $5 \%$ of probability. Values on the same line followed by the same letter did not differ significantly. $L^{*}=$ luminosity or brilliance, varying from black (0) to white (100); $\mathrm{a}^{*}=$ red intensity; $\mathrm{b}^{*}=$ yellow intensity; $\Delta \mathrm{E}=$ difference in color

The cheese bread with total substitution of the fat was the one that presented the greatest difference in color.

The difference in the color between the crust and the center of the bread increased with the increase in the level of substitute in the samples. The crust had a darker yellow color with a higher degree of luminosity than the center.

\section{Cost/benefit relationship}

The caloric value, the reduction in calories, the lipid content, the reduction in lipid content and the cost of the products prepared with five levels of fat substitution by the Dairy-lo protein concentrate are presented in Table 4. The Directive No. 27 of 13/01/98 of the Secretaria de Vigilancia Sanitária/MS (Brasil, 1998) defines the product light as that food which presents a reduction in caloric content of at least $25 \%$ and a difference greater than $40 \mathrm{kcal} / 100 \mathrm{~g}$ relative to the traditional product [that of Jesus (1997), designated P2]. All of the cheese breads prepared with a protein concentrate were in accordance with this requirement when compared to the cheese bread produced by Jesus (1997). Therefore, according to the legislation, the products could be considered as light. The product containing the fat substitute may also be considered light because of the reduction in fat content which is greater than the minimum of $25 \%$ (or $3 \mathrm{~g} / 100 \mathrm{~g}$ of product). It should be noted that the basic formulation used can also be considered as light when compared to the traditional product (P2).

As seen in Table 4, the cost of the cheese breads containing Dairy-lo was higher than that of the reference sample. There was an increase of approximately $30 \%$ relative to the cost of the reference cheese bread when the fat was completely substituted by the protein concentrate. Considering that, for commercialization of the 
cheese bread, the ideal would be the use of lower levels of substitution that would result in products only slightly more expensive than that obtained using the basic formulation, one could conclude that the production of cheese bread containing a protein concentrate is viable.

\section{Overall performance}

No problems were encountered in the preparation of the cheese bread dough containing Dairy-lo. It had a texture similar to the dough of the commercially available product. The cheese breads containing up to $75 \%$ of substitution presented a good performance in the characteristics evaluated. The general physical properties of the experimental breads were better than those of the reference sample. Only the expansion coefficients for levels of substitution greater than $75 \%$ were a little lower than those of the reference sample. Both the crust and the center of the cheese breads presented a darker yellow color than that of the reference cheese bread for all levels of substitution. The cheese bread with as much as $50 \%$ of substitution achieved the objective of caloric reduction while maintaining the normal physical and sensory properties of the product.

Table 4 - Calorie content, lipid content and cost of the cheese bread products produced using a protein concentrate.

\begin{tabular}{lrrrrrrr}
\hline & & & \multicolumn{5}{c}{ Degree of Substitution (\%) } \\
\cline { 5 - 8 } & $\mathbf{P 1}^{\mathbf{3}}$ & $\mathbf{P 2}^{\mathbf{4}}$ & \multicolumn{1}{c}{$\mathbf{1 0}$} & \multicolumn{1}{c}{$\mathbf{2 5}$} & \multicolumn{1}{c}{$\mathbf{5 0}$} & \multicolumn{1}{c}{$\mathbf{7 5}$} & \multicolumn{1}{c}{$\mathbf{1 0 0}$} \\
\hline Calorie content (kcal/100 g) & 263 & 353 & 261.12 & 257.83 & 252.35 & 246.86 & 241.38 \\
Reduction in calories (\%) vs. P1 & - & - & 0.83 & 2.08 & 4.16 & 6.25 & 8.33 \\
Reduction in calories (\%) vs. P2 & 25.50 & - & 26.03 & 26.96 & 28.51 & 30.07 & 31.62 \\
Lipid content/100 g of product & 9.82 & 16.00 & 9.40 & 8.77 & 7.71 & 6.65 & 5.59 \\
Reduction in lipids (\%) vs. P1 & - & - & 4.31 & 10.77 & 21.54 & 32.31 & 43.09 \\
Reduction in lipids (\%) vs. P2 & 38.63 & - & 41.25 & 45.19 & 51.81 & 58.44 & 65.06 \\
Cost of the product (R\$)/kg & 2.07 & 2.02 & 2.13 & 2.22 & 2.38 & 2.53 & 2.69 \\
\hline
\end{tabular}

${ }^{\mathrm{T}}$ Relative to the mass of oil used in the reference formulation.

${ }^{2}$ Calorie and lipid contents were calculated from the data in Franco (1992) and information supplied by the producer of Dairy-lo.

${ }^{3} \mathrm{P} 1$ refers to the cheese bread produced using the reference formulation.

${ }^{4} \mathrm{P} 2$ refers to the formulation used by Jesus (1997)

${ }^{5}$ Cost of the starting material based on the prices of the products in the commerce in Belo Horizonte, MG, in August, 2000.

\section{CONCLUSIONS}

The cheese breads prepared with different protein concentrate contents presented small sensorial variations compared with the reference formula containing $10 \%$ oil content. The general physical properties of the samples containing protein concentrate indicated a better quality than that of the reference cheese bread, only the values of the expansion coefficients for levels of substitution greater than $75 \%$ were slightly lower than that of the reference sample. The cheese breads presented a more intense yellow color, both of the crust and the center, than that of the reference sample for all levels of substitution.

The reduction in calorie content, while maintaining the desired physical and sensorial properties of the product, was achieved with cheese breads containing up to $50 \%$ of substitution. A reduction in total lipid content of $51.81 \%$ relative to that of the traditional formula (P2) was also achieved in samples having a degree of substitution of $50 \%$. This value was much greater than that which the law determined for light products. The reduction in calories was $29 \%$ relative to the formula (P2) of Jesus (1997). Therefore, the cheese bread can be denominated light.

\section{RESUMO}

O pão de queijo, produto típico do estado de Minas Gerais, Brasil, apresenta elevado valor calórico comparado com outros alimentos, cerca de $300 \mathrm{kcal} / 100 \mathrm{~g}$. Os efeitos da utilização de um 
concentrado protéico como um substituto de gordura na qualidade do pão de queijo foram investigados. A partir de uma formulação com $10 \%$ de óleo foi testada a substituição de 10,25 , 50,75 e $100 \%$ do teor de óleo. As amostras foram avaliadas sensorialmente e suas propriedades físicas foram determinadas. Os pães de queijo com menor substituição da gordura apresentaram maior nível de aceitação. Com o aumento do nível de substituição, os pães de queijo apresentaram pior aparência, tornaram-se mais duros, com maior espessura da crosta, sabor de queijo menos pronunciado e com menor grau de aceitação. $\mathrm{O}$ uso do substituto de gordura acarretou um decréscimo substancial no teor lipídico e redução calórica superior a $25 \%$.

\section{REFERENCES}

Akoh, C. C. (1998), Fat replacers. Food Technol., 52, 47-53.

Anzaldúa-Morales, A. (1994), La evaluación sensorial de los alimentos en la teoria y la práctica. Zaragoza: Acribia. 198 pp.

Barndt, R. L. and Antenucci, R. N. (1993), Fat and calorie-modified bakery products. In: KHAN, R. Low-calorie foods and food ingredients. London: Blackie. pp. 106-137.

Brasil. Ministério da Saúde. (16 de janeiro, 1998), Portaria n. 27, de 13 de janeiro de 1998. Aprova o regulamento técnico referente à informação nutricional complementar. Diário Oficial, Brasília.

Cândido, L. M. B. and Campos, A. M. (1995), Alimentos para fins especiais: dietéticos. São Paulo: Varela. 423 pp.

Clareto, S. S. (2000), Influência da formulação e da adição de substitutos de gordura na qualidade de pão de queijo. Masters Dissertation, Universidade Federal de Minas Gerais, Belo Horizonte, MG, 83 pp.

Franco, G. (1992), Tabela de composição química dos alimentos. 9. ed. São Paulo: Atheneu. 307 pp.

Griswold, R. M. (1972), Estudo experimental dos alimentos. São Paulo: USP. 469 pp.

IAL (Instituto Adolfo Lutz), (1985), Normas analíticas do Instituto Adolfo Lutz: métodos químicos e físicos para análises de alimentos. $3^{\text {rd }}$ ed. São Paulo: IAL. 533 pp.

Jesus, C. C. (1997), Contribuição para a caracterização físico-química e sensorial do pão de queijo. Masters Dissertation, Universidade Federal de Minas Gerais, Belo Horizonte, MG. 103 pp.

Lucca, P. A. and Tepper, B. J. (1994), Fat replacers and the functionality of fat in foods. Trends in Food Sci. Technol., 5, 12-19.
Mitchell, H. L. (1993), Novel milk protein concentrated for low fat foods. Int. Food Ingred., 5, 25-28.

Montgomery, D. C. (1984), Design and analysis of experiments. $2^{\text {nd }}$ ed. New York: John Wiley. 538 pp.

Pereira, A. J. G. (1998), Fatores que afetam a qualidade do pão de queijo. Belo Horizonte: CETEC. $52 \mathrm{pp}$.

Pereira, A. J. G.; Jesus, C. C. and Laboissière, L. H. E. S. (1995), Caracterização físico-química, microbiológica e sensorial do pão de queijo. In: Simpósio Latino Americano de Ciência de Alimentos, Campinas. Anais ... Campinas. pp. 63.

Shirose, I. and Mori, E. E. M. (1994) Estatística aplicada à análise sensorial (Módulo 1). Campinas Unicamp. 73 pp. (Manual Técnico - ITAL, 13).

Wonnacott, R. J. and Wonnacott, T. H. (1985), Fundamentos de estatística. Rio de Janeiro: Livros Técnicos Científicos. 355 pp. 